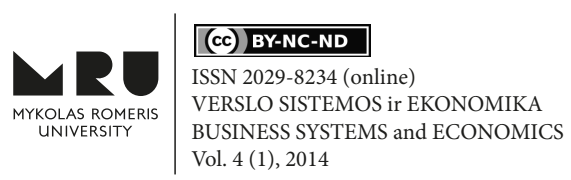

\title{
RISKS ASSESSMENT OF TRADE SERVICES
}

\author{
Inga JANSONE \\ Riga Technical University \\ Faculty of Engineering Economics and Management \\ Kalnciema str. 6, 407, Riga, LV 1007, Latvia \\ E-mail: Inga.Jansone_1@rtu.lv \\ Irina VORONOVA \\ Riga Technical University \\ Faculty of Engineering Economics and Management \\ Kalnciema str. 6, 407, Riga, LV 1007, Latvia \\ E-mail: Irina.Voronova@rtu.lv \\ doi:10.13165/VSE-14-4-1-01
}

\begin{abstract}
The goal of the research is to study types of risks, their identification and classification and assessment possibilities in activities of Latvian trade services enterprises. The authors have created classification of the trade services technological process risks and have carried out a survey of the most important risk factors in the stages of the trade services technological process. Also, the authors have created the trade services technological process risks matrix. The risks matrix is a quantitative assessment of risks. Risks have been arranged by their size of possible losses. The experts' method for economic risks assessment has been used and a model of enterprises' risks identification, classification and assessment for the trade services sector of Latvia has been made. The authors have used their own created model of enterprises' risks identification, classification and assessment to research economic and financial risks by their effect on Latvian trade services sector enterprises' development. From the year 2004 till the year 2011, the authors studied medium financial indexes of trade services enterprises in Latvia. Based on economic analysis of trade services enterprises' medium financial indexes, risk-level dynamics assessment has been created, using the special coefficient method.
\end{abstract}

Keywords: classification of risks, risks assessment, risks matrixes, trade services technological process risks.

JEL classification: G32.

\section{Introduction}

It is important for enterprises, operating in the Latvian trade services sector, to create an efficient economic activity in both economic growth and economic slowdown, where economic activity expansion opportunities are evaluated and risks are associated with changes 
of economic activities. It is necessary for enterprises to follow changes of economic activities, to assess the risk of financial instability and prevent the risk of insolvency (bankruptcy). Enterprises have to assess marketing activities to attract new and retain existing customers in retail stores, as well as create marketing activities that increase customer loyalty to store chain's brand. Marketing activities should promote customers to buy in a particular chain of stores regularly. As well as small and medium companies are merging into trade cooperation and a chain of stores, the strategy of economic activity in the trade services sector and working with the common retail trade brands are jointly implemented. It is important to review contracts with the suppliers, its conditions and commodity prices, discounts and terms of delivery and deferred payment days. Evaluating the mentioned aspects, enterprises can develop the strategy to effectively carry out their business activities in the Latvian trade services sector. In order to develop its business strategy, enterprises need to identify, classify and evaluate Latvian trade services sector's risks. The research object is the Latvian trade services sector from 2004 till 2012. The research subject is trade services sector risks assessment. The authors have used scientific research methods - analysis and synthesis methods, the economic analysis method of enterprises, the special coefficient method, the risks ranking method and the experts' method.

\section{Literature review}

Komkova (2008) researched major risk management problems in Latvian non-financial companies. Most of enterprises do not have an insight about the need of the risk management implementation. The practical risk management implementation is not possible without relevant risk models adaptation to Latvian economic situation. Also, there is a lack of experience in implementation and adaptation of risk management. Zimecs and Ketners (2009) researched the importance of risk management for small and medium-sized enterprises. It is important for their entrepreneurs to understand and create a system of risk management. This system of risk management should be integrated into enterprises development strategies and could also be used for increasing the level of enterprise competitiveness. Zimecs and Ketners (2010) also studied business solution methodologies and their impact on risk management and carried out a survey of risk management developments. As shown by the survey results, the entrepreneurs, who use the risk management elements in their daily activities, mainly manage risks by using information of business results.

Jansone, Nespors and Voronova (2010) researched the impact of financial and economic risks to extension of food retail industry (sector) of Latvia. The authors recommended using Altmana model (adapted for Latvia by RTU scientists Sorins and Voronova). Test results for trade services sector enterprises showed that forecasting accuracy of F14 - the risk of insolvency (bankruptcy) - is more than $80 \%$ for both models (Atmana model, Sorins and Voronova model). Jansone and Voronova (2010) studied financial stability problems of Latvian trade services sector enterprises. Jansone and Voronova (2011) also researched external and internal risks impact on the development of Latvian trade services sector enterprises. The authors created the Latvian trade sector external and internal risks ranking (with a risks ranking method). Values of the total external risks and the total internal risks are almost equal (difference is 5\%), so both risks have an important impact on the Latvian trade sector enterprises' development. In addition, Jansone and Voronova (2012a) researched the 
external and internal risks impact on the development of Latvian accommodation (hotel) and food services sector enterprises. Voronova (2008) studied risks identification and classification problems. Also, Voronova (2012) studied financial risks and possibilities to assess them, as well as financial stability models, which are adapted for other countries (for circumstances of an individual country).

Stasytyte (2012) researched the adequate methods and tools for implementing an intelligent risk management. According to the risk intelligence maturity model, a risk-intelligent company management could be achieved by identifying on what risk management step the company currently stands and designing a strategy of moving forward to the next step till it reaches the risk management intelligence. Rutkauskas (2008) studied advantages of sustainable competitive enterprise, considering risks and their impact on enterprise's development. The important stage of risk management is risk identification and classification. Pirogova (2010) researched development and stability problems of trade services enterprises. Simultaneous guarantee of both trade enterprises' economic activity growth and enterprises' stability may create a mutual conflict. An increase of development rates may increase the total level of the trade enterprises' risk and increase the risk of financial instability.

\section{Latvian trade services sector analysis during the period from 2004 to 2012}

For Latvian trade sector analysis, NACE Rev. 2 has been used, which is a statistical classification of information about economic activities. Section $G$ includes information of wholesale and retail trade, repair of motor vehicles and motorcycles. The authors have researched divisions of the total Latvian trade services sector turnover in 2011. Division 45 includes all activities related to the sale and repair of motor vehicles and motorcycles. The turnover of this division is the lowest and it forms $7.1 \%$ of the total Latvian trade services sector turnover. Division 46 includes all activities related to the wholesale. The turnover of this division is $65.8 \%$ of the total Latvian trade services sector turnover. Division 47 includes all activities related to the retail trade. The turnover of this division is $27.1 \%$ of the total Latvian trade services sector turnover.

In the period from 2004 to 2012, total turnover indexes of Latvian selling and repairing motor vehicles and motorcycles enterprises increased and reached the highest value in 2007. In this period, the growth of the sector was observed. Since 2008, division 45 has started to decline. In 2009, turnover indexes of Latvian selling and repairing motor vehicles and motorcycles enterprises reached the lowest value. From 2010, total turnover indexes have begun to increase.

In the period from 2004 to 2012, total turnover indexes of Latvian wholesale enterprises increased and reached the highest value in 2007. In this period, the growth of the sector was observed. Since 2008, division 46 has started to decline. In 2009, turnover indexes of Latvian wholesale enterprises reached the lowest value. From 2010, total turnover indexes have begun to increase. In 2012, turnover indexes of Latvian wholesale enterprises reached the value, which exceeded the value of the year 2007. 
Figure 1: Total turnover indexes of Latvian wholesale enterprises in the period from 2004 to 2012 , $(\%)(2010=100)$

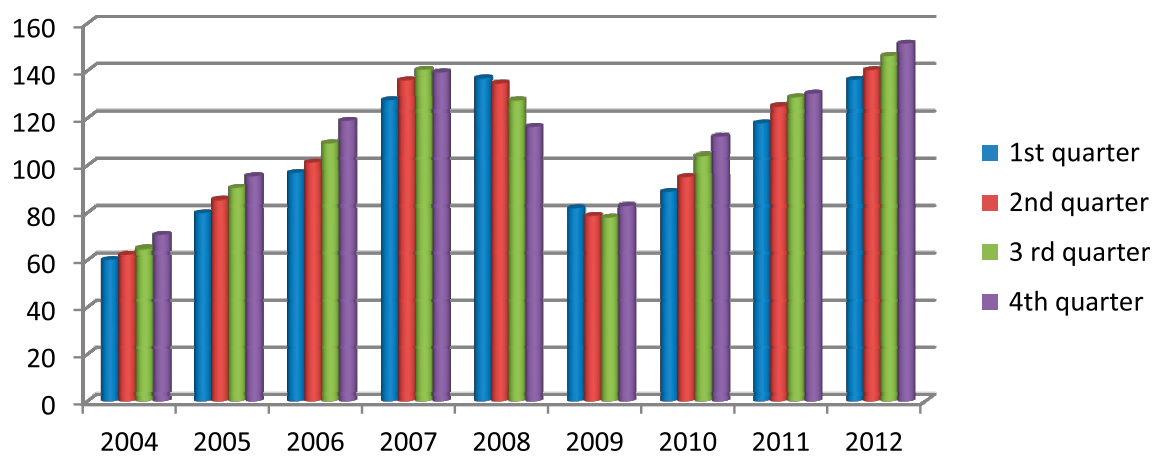

Source: Central Statistical Bureau of Latvia (2013)

In the period from 2004 to 2012, total turnover indexes of Latvian retail trade enterprises increased and reached the highest value in 2007. In this period, the growth of the sector was observed. Since 2008, division 47 has started to decline. In 2009, turnover indexes of Latvian retail trade enterprises reached the lowest value (the same values as in 2004). From 2010, total turnover indexes have begun to increase. At the end of 2012, turnover indexes of Latvian retail trade enterprises returned to the same values as in 2005.

\section{Technological process risks of trade services}

The authors have created a classification of technological process risks of trade services. Trade services technological process consists of wholesale and retail trade. The authors justified the classification in the stage of technological process of trade services. Describing specific risks, the causes of possible losses are shown. According to Borovkova (2004), technological process map of trade services shows the trade services enterprises cooperation with suppliers and buyers. Enterprises' economic activities are realized through the main functions of the trade services - supplies of goods (choice of economically effective goods' distribution channel as well as planning transportation of goods); storage of goods (analyzing and planning of goods' stocks as well as separation of goods and completion of goods); activities of goods' realization (market analysis, preparation (packing) of goods for retail trade, planning and organizing promotional activities of goods' realization and organization of customers' service. 
Table 1: Classification and description of trade services technological process risks

\begin{tabular}{|c|c|c|}
\hline $\begin{array}{l}\text { Stage of trade services } \\
\text { technological process }\end{array}$ & $\begin{array}{l}\text { Risk of trade services } \\
\text { technological process }\end{array}$ & Description of risk \\
\hline $\begin{array}{l}\text { Acceptance of goods in } \\
\text { wholesale warehouse and } \\
\text { retail trade store }\end{array}$ & $\begin{array}{l}\text { P1. Risk of acceptance of } \\
\text { goods }\end{array}$ & $\begin{array}{l}\text { Possible loss if the goods do not fit with } \\
\text { quality and quantity of attendant docu- } \\
\text { mentation }\end{array}$ \\
\hline $\begin{array}{l}\text { Storage of goods in whole- } \\
\text { sale warehouse and retail } \\
\text { store }\end{array}$ & P2. Risk of storage of goods & $\begin{array}{l}\text { Possible loss if the storing goods lose } \\
\text { their use-value }\end{array}$ \\
\hline Preparation for order & P3. Risk of ordering goods & $\begin{array}{l}\text { Acceptance of order, qualitative se- } \\
\text { lection and collection of goods }\end{array}$ \\
\hline \begin{tabular}{|l|} 
Loading of goods in a \\
transporter
\end{tabular} & P4. Risk of loading goods & $\begin{array}{l}\text { Placing of goods in a transporter that } \\
\text { minimizes the possibility of damage }\end{array}$ \\
\hline $\begin{array}{l}\text { Transportation of goods, } \\
\text { placing of goods in the } \\
\text { shopping hall }\end{array}$ & $\begin{array}{l}\text { P5. Risk of transportation of } \\
\text { goods }\end{array}$ & $\begin{array}{l}\text { Possible loss during transportation of } \\
\text { goods, because reloading can decrease } \\
\text { quality of goods }\end{array}$ \\
\hline $\begin{array}{l}\text { Preparation (packing) of } \\
\text { goods in the storehouse } \\
\text { room of retail trade }\end{array}$ & $\begin{array}{l}\text { P6. Risk of goods preparation } \\
\text { for retail trade }\end{array}$ & $\begin{array}{l}\text { Possible loss if workers do not have the } \\
\text { necessary skills for job }\end{array}$ \\
\hline $\begin{array}{l}\text { Purchasing of trade equi- } \\
\text { pment and package }\end{array}$ & $\begin{array}{l}\text { P7. Risk of operation of trade } \\
\text { equipment }\end{array}$ & $\begin{array}{l}\text { Purchase of a new trade equipment and } \\
\text { regular maintenance of equipment }\end{array}$ \\
\hline Sale of goods in retail trade & $\begin{array}{l}\text { P8. Risk of organization of } \\
\text { selling goods }\end{array}$ & $\begin{array}{l}\text { Customers' service at the cash register } \\
\text { when selling goods }\end{array}$ \\
\hline Guarantee service of goods & $\begin{array}{l}\text { P9. Risk of execution of go- } \\
\text { ods' guarantee service }\end{array}$ & $\begin{array}{l}\text { Possible loss if the goods need to be } \\
\text { repaired by guarantee }\end{array}$ \\
\hline $\begin{array}{l}\text { All stages of trade services } \\
\text { technological process }\end{array}$ & P10. Risk of accounting & $\begin{array}{l}\text { Process of accounting in wholesale and } \\
\text { retail trade store }\end{array}$ \\
\hline
\end{tabular}

Source: created by the authors (2013)

The authors have carried out a survey of the most important risk factors in the stages of the trade services technological process:

1. Qualitative and quantitative acceptance of goods from the supplier in the distribution centre according to accompanying documents. There is storage of goods in the distribution centre, goods accounting realization at distribution centre, goods balance assessment and choice of new goods order amount and assortment, goods order preparation at the distribution centre. It is necessary to prepare a selection of goods in accordance with the order.

2. It is important to prepare loading of goods in a transporter according to safe transporting requirements and to develop an optimal transportation route. Goods are transported to the shop. It is necessary to perform the qualitative and quantitative acceptance of goods from the supplier in shop's warehouse according to the accompanying documents.

3. Goods storage at shop's warehouse according to the requirements which are shown on good's packing and in accompanying documents. It is important to do the preparation of goods in shop's warehouse, dividing goods into smaller packing and packaging into packing of special material.

4. Transport goods from the warehouse to the shopping hall. Place goods into shelves or in freezers. It is necessary to do goods accounting realization at the shop's warehouse and shopping hall. In addition, it is necessary to perform goods balance as- 
sessment and choice of new goods order amount and assortment, regularly follow on goods movement on shelves. Moreover, it is important to do goods price reduction or conversion to the supplier on time.

5. It is important to purchase new trade equipment, to do regular preventive maintenance of goods and to do necessary repairs. It is necessary to order and deliver packaging material.

6. It is important to have customers' services at the cash register when selling goods. It is necessary to do goods accounting according to its amount, weight and price. When a customer pays cash, then he gets a cashier's check with the remaining amount of money. When the customer pays by credit card, then he gets only a cashier's check.

7. If the product has guarantee service, then the customer also has a product warranty card with a buying date. If the product needs to be repaired, addresses of repairs offices are shown on the product warranty card.

The authors have carried out a survey of additional factors for successful retail trade:

1. The place is one of the most important factors. The retail trade shop must be located in a place, where it is easy and comfortable for buyers' driveways by cars and walkers are available.

2. The assortment of goods and the amount of them must be such that are able to offer buyers products according to their needs and wishes.

3. The appropriate level of customer service will ensure that customers will be satisfied and will return to the store after repeated purchases. The price level must comply with the buyers' solvency of the chosen market segment.

The authors have created the trade services technological process risks matrix.

Figure 2: Trade services technological process risks matrix

\begin{tabular}{|c|c|c|c|c|c|c|c|c|c|c|}
\hline \multicolumn{11}{|l|}{$0.6-0.8$} \\
\hline $0.4-0.6$ & & & \multicolumn{2}{|l|}{$\begin{array}{l}\text { P4 } \\
\text { P2 }\end{array}$} & \multicolumn{2}{|l|}{ P5 } & \multicolumn{2}{|l|}{ P10 } & & \\
\hline $0.3-0.4$ & & & \multicolumn{2}{|c|}{$\begin{array}{ll}\text { P6 } & \text { P7 } \\
\text { P9 } & \end{array}$} & \multicolumn{2}{|l|}{$\begin{array}{l}\text { P1 } \\
\text { P3 }\end{array}$} & \multicolumn{2}{|l|}{ P8 } & & \\
\hline \multicolumn{11}{|l|}{$0.1-0.3$} \\
\hline Scale $a_{i}$ & 1 & 2 & 3 & 4 & 5 & 6 & 7 & 8 & 9 & 10 \\
\hline $\begin{array}{l}\text { Probability of } \\
\text { realization }\end{array}$ & \multicolumn{2}{|c|}{$\begin{array}{l}\text { Small } \\
\text { risk }\end{array}$} & \multicolumn{2}{|c|}{$\begin{array}{l}\text { Medium } \\
\text { risk }\end{array}$} & \multicolumn{2}{|c|}{ Big risk } & \multicolumn{2}{|c|}{$\begin{array}{l}\text { Maximum } \\
\text { acceptable } \\
\text { risk }\end{array}$} & \multicolumn{2}{|c|}{ Critical risk } \\
\hline \multicolumn{11}{|c|}{ characteristics of the size of risk (losses) } \\
\hline
\end{tabular}

Source: created by the authors (2013)

The risks matrix is a quantitative assessment tool of risks. It implies a certain form of subjective (expert) gradation of risks. The main principle for constructing risks matrixes is based on generalizing risk event frequency and severity of its impact. Also, risks 
are classified by size: maximum acceptable risk - risk when possible amount of losses is smaller than possible amount of profit; critical risk - risk when possible amount of losses is larger or equal than possible amount of profit. The authors have arranged risks by their size of possible losses. According to each type of risk, its probability of realization has been assessed. The most important trade services technological process risks, which may lead to the largest losses, are the following ones: P10 - the risk of accounting; P8 - the risk of organization of selling goods; P5 - the risk of transportation of goods; P1 - the risk of acceptance of goods.

\section{Identification, classification and assessment of trade services sector risks}

The authors have researched types of risks, their identification, classification and assessment possibilities. The purpose of the first International risk management standard ISO 31000 (2009) is to provide principles and generic guidelines on risk management. Risk is an effect of uncertainty on objectives. The impact of risk could be negative (losses) or positive (profit). If a negative impact of risks is studied, then the amount of risk characterizes a possible amount of results (losses) and probability of realization. The process of risk assessment includes identification and classification of risk and risk analysis of quality and quantity. In risk identification process, it is important to identify sources of risk, areas of impacts, events (including changes in circumstances) and their causes as well as their potential consequences. For the classification of risks, the authors have applied a methodological basis, which allows considering risk classification to be coherent in terms of its sources and cost, flexible (adjustable) and corresponding to the principles of business management. The classification of risks means to range them by specific characteristics. The financial risk is the possibility of the financial resources' losses by its financial default or failure of financial management. The economic risk is the decline of enterprises' competitiveness and the possibility of losses by unforeseen changes in the economic situation.

Jansone and Voronova (2012b) used their own created algorithm of enterprises risks' identification, classification and assessment for accommodation and food services sector of Latvia. Jansone and Voronova (2013a) used the experts' method for economic risks assessment and made a model of enterprises risks' identification, classification and assessment for the trade services sector of Latvia (see Figure 3). Important stages of the above mentioned model are the following ones:

1. Make SWOT analysis of the Latvian trade services sector;

2. Get to know surveys of the major risks in the world;

3. Create the classification and description of technological process risks of trade services;

4. Assess risks in order to create risks matrix;

5. Assess risks by using the special coefficient method;

6. Assess risks by using the experts' method;

7. Assess risks by using a questionnaire of enterprises about risks;

8. Rank external and internal risks by their impact on sector enterprises' development. 
Figure 3: Model of enterprises' risks identification, classification and assessment for the trade services sector of Latvia

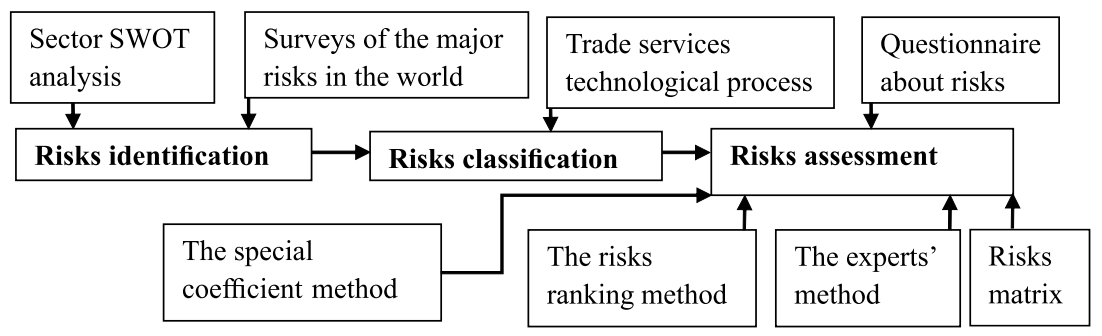

Source: created by the authors (2013)

The authors have used the experts' method for economic risks assessment. For experts, it is easier to compare risks in pairs than all risks rank at once, whereas the authors offer the economic risks (from E1 till E7) $(n=7)$ experts assessment of the risks comparing in pairs. The authors have been working with an expert group of five $(m=5)$. Each expert fills the matrix. The expert gives the value of one for risk assessment if he considers that the given risk (object) $\mathrm{Xi}$ is greater than the comparative risk (object) Xf. The check box of the common matrix shows how many experts have given a preference for a particular risk

Table 3: Common matrix of the experts' assessment

\begin{tabular}{|c|c|c|c|c|c|c|c|c|}
\hline $\begin{array}{c}X_{f} \\
X_{i}\end{array}$ & E1 & E2 & E3 & E4 & E5 & E6 & E7 & $\sum Y_{i f}$ \\
\hline E1 & $Y_{i f}$ & 0 & 1 & 1 & 0 & 1 & 0 & 3 \\
\hline E2 & 5 & $Y_{i f}$ & 4 & 4 & 1 & 4 & 3 & 21 \\
\hline E3 & 4 & 1 & $Y_{i f}$ & 1 & 0 & 1 & 1 & 8 \\
\hline E4 & 4 & 1 & 4 & $Y_{i f}$ & 0 & 4 & 0 & 13 \\
\hline E5 & 5 & 4 & 5 & 5 & $Y_{i f}$ & 4 & 4 & 27 \\
\hline E6 & 4 & 1 & 4 & 1 & 1 & $Y_{i f}$ & 3 & 14 \\
\hline E7 & 5 & 2 & 4 & 5 & 1 & 2 & $Y_{i f}$ & 19 \\
\hline
\end{tabular}

Source: created by the authors (2013)

Numeral of the matrix box Yif shows how many experts preferred the object Xi to the object Xf. As the number of the experts is five, then the total number is five in every assessment of risks.

According to Markovics (2009), a consensus degree of an expert opinion is determined by the formula [1]. The sum extends over the check boxes, which are located below the diagonal.

$$
V=\frac{4 \cdot\left(\sum Y_{i f}{ }^{2}-m \cdot \sum Y_{i f}+C_{n}^{2} \cdot C_{m}^{2}\right)}{m \cdot(m-1) \cdot n(n-1)}
$$

where $V$ is a consensus degree of an expert opinion;

$\begin{array}{ll}Y_{i f} \text { is a value of the matrix; } & C_{m}^{2} \text { is a number of combinations in pairs elements; } \\ m \text { - a number of experts; } & n \text { - a number of assessed risks. }\end{array}$ 
To complete coincidence of the experts' opinion $V=1$, the authors established the consensus degree of the experts' opinion required level $(V=0.61)$. Then, work on the calculation of the resulting ranking of each risk starts. It is obtained from the matrix that it is necessary to add a column, which records the total amount of each row. The resulting ranking of each risk is obtained from the matrix, adding a column, which records the total amount of each row. The major risks, according to the assessment of the experts, are the risk of reduction in client's solvency (E5), the risk of increment of taxes (E2), the risk of increasing competition (E7) and the risk of insufficiency of credit resources (E6).

Jansone and Voronova (2013b) assessed Latvian trade sector risks by using the special coefficient method.

Table 2: Assessment of Latvian trade sector risks dynamic by using the special coefficient method in the period from the year 2004 till the year 2011

\begin{tabular}{|c|c|c|c|c|c|c|c|c|c|}
\hline$\frac{\text { Title of ratio }}{\text { Type of risk }}$ & $\mathrm{D}$ & 2004 & 2005 & 2006 & 2007 & 2008 & 2009 & 2010 & 2011 \\
\hline \multicolumn{10}{|l|}{ Liquidity ratio } \\
\hline $\begin{array}{l}\text { The current ratio } \\
\text { The risk of liquidity }\end{array}$ & $\frac{D_{d}}{D_{\text {in }}}$ & 1.23 & 1.21 & 1.19 & 1.18 & 1.14 & 1.06 & 1.12 & 1.18 \\
\hline \multicolumn{10}{|l|}{ Activity ratios } \\
\hline $\begin{array}{l}\text { Inventory turnover ratio } \\
\text { The risk of turnover of } \\
\text { inventory (stocks) }\end{array}$ & $\frac{D_{\text {in }}}{D_{d}}$ & 9.23 & 8.90 & 9.25 & 8.22 & 6.80 & 6.11 & 8.43 & 9.46 \\
\hline $\begin{array}{l}\text { Average collection period } \\
\text { (days) } \\
\text { The risk of debtors }\end{array}$ & $\frac{D_{\text {in }}}{D_{\text {in }}}$ & 41 & 43 & 41 & 43 & 54 & 65 & 51 & 44 \\
\hline \multicolumn{10}{|l|}{ Profitability ratios } \\
\hline $\begin{array}{l}\text { Return on assets (ROA) } \\
\text { The risk of profitability of } \\
\text { assets }\end{array}$ & $\frac{D_{d}}{D_{\text {in }}}$ & 0.04 & 0.05 & 0.06 & 0.06 & 0.02 & -0.04 & 0.005 & 0.026 \\
\hline $\begin{array}{l}\text { Return on equity (ROE) } \\
\text { The risk of profitability of } \\
\text { equity (own) capital }\end{array}$ & $\frac{D_{d}}{D_{\text {in }}}$ & 19,51 & 22,90 & 30,60 & 30,34 & 7.55 & -23.01 & 3.00 & 14.85 \\
\hline \multicolumn{10}{|l|}{ Solvency ratio } \\
\hline $\begin{array}{l}\text { Debt to equity ratio } \\
\text { The risk of financial ins- } \\
\text { tability }\end{array}$ & $\frac{D_{\text {in }}}{D_{\text {in }}}$ & 3.72 & 3.86 & 3.98 & 3.70 & 3.98 & 5.48 & 5.01 & 4.27 \\
\hline
\end{tabular}

Source: Central Statistical Bureau of Latvia (2013)

Symbols adopted for Table 3: $D$ - the symbol of risk (index) dynamic: $D_{i n}-$ level of risk (index) increases; $D_{d}$ - level of risk (index) decreases.

From 2004 till 2011, the authors studied average financial indexes of Latvian trade services sector enterprises and did the economic analysis. According to Pettere and Voronova (2003), ratios (indexes) of the special coefficient method are liquidity, profitability, solvency and activity (circulation). The current ratio decreases and, as a result, the risk of liquidity increases. The inventory turnover ratio increases and, as a result, the risk of turnover of inventory (stocks) decreases. The average collection period (days) increases and, as a result, the risk of debtors increases. The return on assets (ROA) decreases and the risk of profit- 
ability of assets increases. The return on equity (ROE) decreases and the risk of profitability of equity (own) capital increases. Debt to equity ratio increases and, as a result, the risk of financial instability increases.

The authors have become acquainted with the questionnaires of enterprises about risks (the questionnaires are from different countries). Henschel (2010) studied German small and medium-sized enterprises' risk management problems and carried out a questionnaire of enterprises about it. According to the questionnaire results, if one performs the risk management system, then the size of the enterprise is the uppermost factor. The bigger the enterprise, the detailed and completed is its risk management system. Korombela (2012) studied risk management problems of Polish small and medium-sized enterprises and carried out a questionnaire about it. The most important risks were F5 - the risk of financial instability, E7 - the risk of increasing competition, and E1 - the risk of legislative changes.

Latvian trade services sector is a subsector of the Latvian services sector. Jansone and Voronova (2012c) created a classification of Latvian services sector's economic and financial risks in the period from 2011 to 2012 . For the quantity of economic and financial risk assessment of Latvian services sector enterprises, Jansone and Voronova (2012d) created the risks matrix. Most of the authors classified Latvian services sector economic and financial risk magnitudes from the medium till maximum acceptable magnitude. The probability of risks realization is from 0.2 till 0.6 . Those risks have been included in the questionnaire. The authors have prepared a questionnaire about enterprise's activity and economic and financial risk assessment about the possible amount of losses. The authors have carried out a questionnaire, where representatives of small and medium-sized enterprises gave information about economic and financial risk's impact on the enterprise's development in 2012.

Representatives of the questionnaire have assessed the possible amount of losses of economic and financial risks (value 5 means the maximum losses). The majority of the enterprises, which participated in the questionnaire, were medium-sized enterprises. From the enterprises, which participated in the questionnaire, there were medium-sized enterprises (48.6\%), small enterprises (40.0\%) and micro enterprises (11.4\%). The questionnaire's participants assessed economic risks and ranked them by the possible amount of losses. The biggest losses were possible from the impact of these risks: the risk of reduction in client's solvency (E5), the risk of increment of taxes (E2) and the risk of increasing competition (E7). The questionnaire's participants assessed financial risks and ranked them by the possible amount of losses. The biggest losses were possible from the impact of these risks: the risk of debtors (F9), the risk of insufficiency of the current assets (F8), the risk of inflation (F4), the risk of unpaid credit (F1) and the monetary risk (F3).

\section{Conclusion}

The authors have researched types of risks, their identification, classification and assessment possibilities. The authors have used their own created model of enterprises' risks identification, classification and assessment to research economic and financial risks according to their effect on the Latvian trade services sector enterprises' development. The authors have also carried out a survey of the most important risk factors in the stages of the trade services technological process. They have created a classification of trade services technological process risks and the trade services technological process risks matrix. The 
most important trade services technological process risks, which may lead to the largest losses, are the risk of accounting (P10) and the risk of organization of selling goods (P8). The authors have assessed Latvian trade services sector risks by using the special coefficient method. The risks assessment by using the special coefficient method demonstrated that Latvian trade services sector risks increased in the period from 2004 till 2011. The authors have carried out a questionnaire, where representatives of small and medium-sized enterprises gave information about the economic and financial risk impact on the enterprise's development in 2012. The questionnaire's participants assessed economic risks and ranked them by the possible amount of losses. The biggest losses were possible from the impact of these risks: the risk of reduction in client's solvency (E5), the risk of increment of taxes (E2) and the risk of increasing competition (E7). The questionnaire's participants also assessed financial risks and ranked them by the possible amount of losses. The biggest losses were possible from the impact of these risks: the risk of debtors (F9), the risk of insufficiency of the current assets (F8), and the risk of inflation (F4).

The authors have recommended for the enterprises to use risks matrixes in order to assess different types of risks. For risks quantity assessment, enterprises can use the risks matrix, which arrange risks by their possible amount of losses. According to each type of risk, it is possible to assess its probability of realisation. The authors recommended for the enterprises managers to use the experts' method for risks assessment. The Latvian trade services sector's enterprises can use the model of risks identification, classification and assessment created by the authors and to produce their own risk management systems. The authors have recommended for the enterprises assessing the risk dynamic of financial instability and this risk impact on small and medium-sized enterprises' development, because it is important for enterprises to extend commercial activities and t open new structural subdivisions. The risk matrix can be used to choose enterprise's strategy of risk management. The enterprise's strategy of risk management is developed by analysing zones of risk level.

\section{References}

Боровкова, В. (2004). Управление рисками в торговле. [Risk Management in the Trade]. СПб: Питер.

Central Statistical Bureau of Latvia. (2013). Retrieved September 23, 2013 from http://www.csb.gov.lv

Henschel, T. (2010). Typology of Risk Management Practices: An Empirical Investigation into German SMEs. Journal of International Business and Economic Affairs. 9(3): 1-28.

International Standard ISO3100. (2009). Risk Management - Principles and Guidelines. Retrieved June 25, 2013 from http://calmap.gisc.berkeley.edu/dwh doc link/Technical Background/RAM documents/ISO+31000-2009.pdf

Jansone, I.; Nespors, V., and Voronova, I. (2010). Impact of Financial and Economic Risks to Extension of Food Retail Industry of Latvia. Scientific Journal of RTU: Economics and Business. 20: 59-64. Jansone, I., and Voronova, I. (2010). Assessment Tools of Latvian Trade Sector Enterprises Financial Stability. International Conference "Стратегия антикризисного управления экономическим развитием Российской Федерации”, Russia, Penza, November 7 - October 7, 2010, p. 18-21.

Jansone, I., and Voronova, I. (2011). Latvian Trade Sector External and Internal Risk Assessment. International Conference "The Current Issues in Management of Business and Society Development - 2011", Latvia, Riga, May 5-7, p. 53-54.

Jansone, I., and Voronova, I. (2012). External and Internal Risks Impact on Accommodation and Food Services Sector of Latvia. Scientific Journal of RTU: Economics and Business. 22: 80-87.Jansone, I., and Voronova, I. (2012). Risks Assessment of Accommodation and Food Services Sector: 
The Case of Latvia. 7th International Scientific Conference "Business and Management 2012", Lithuania, Vilnius, May 10-11, 2012, p. 1117-1124.

Jansone, I., and Voronova, I. (2012). Risks Assessment of Small and Medium-Sized Enterprises in Latvia. In: 53rd Riga Technical University Conference "Scientific Conference on Economics and Entrepreneurship” SCEE'2012: Proceedings CD: Riga Technical University 53rd International Scientific Conference. October 11-12, 2012. Riga: RTU FEEM, p. 1-8. ISBN 9789934103551.

Jansone, I., and Voronova, I. (2012). Risks Assessment of Small and Medium-Sized Enterprises: The Case of Latvia. International Conference "Contemporary Issues in Business, Management and Education '2012”, Lithuania, Vilnius, November 15, 2012, p. 91-103.

Jansone, I., and Voronova, I. (2013a). Risks Assessment of Trade Services Sector: The Case of Latvia. In: 54rd Riga Technical University Conference "Scientific Conference on Economy and Entrepreneurship" SCEE '2013: Proceedings C: 1. October 14-16, 2013. Riga. ISBN 9789934103551.

Jansone, I., and Voronova, I. (2013b). Risks Assessment of Trade Services Sector: The Case of Latvia. In: 3rd International Scientific Conference "Whither Our Economies - 2013": Conference Proceedings, Lithuania, Vilnius, October 24-25, 2013. Vilnius: Mykolas Romeris University, p. 161-169.

Komkova, J. (2008). Risk Management Models for Latvian Non-financial Sector Enterprises. Riga: RTU Izdevnieciba.

Korombel, A. (2012). Enterprise Risk Management in Practice of Polish Small Businesses - Own Research Results. 7th International Scientific Conference "Business and Management 2012", Lithuania, Vilnius, May 10-11, p. 1137-1143.

Markovics, Z. (2009). Ekspertu novērtējumu metodes [Experts' Evaluation Methods]. Riga: RTU Izdevniecība.

Pettere, G., and Voronova, I. (2003). Riski uzṇēmèjdarbībā un to vadība. [The Risks in Business and Risks Management]. Riga: Apgāds Rasa ABC.

Пирогова, О. (2010). Особенности обеспечения устойчивости развития торговых предприятий в условиях рыночной экономики. [The Particularly for Providing Sustainability of Trade Enterprises in the Market Economy]. International Conference "Развитие инновационного потенциала отечественных предприятий и формирование направлений его стратегического развития". Пенза, р. 72-82.

Rutkauskas, A. (2008). On the Sustainability of Regional Competitiveness Development Considering Risk. Technological and Economic Development of Economy. 14(1): 89-99. Retrieved June 16, 2013 from http://www.tede.vgtu.lt/en/lt/1/NR /12165Stasytyte, V. (2012). Risk Management Intelligence. International Conference "Contemporary Issues in Business, Management and Education '2012”. Lithuania, Vilnius, November 15, p. 195-206.

Voronova, I. (2008). Methods of Analysis and Estimation of Risks at the Enterprises of Non-financial Sphere of Latvia. Journal of Business Economics and Management. Transition Processes in Central and Eastern Europe. 9(4): 319-326.Voronova, I. (2012). Financial Risks: Cases of Non-Financial Enterprises. Risk Management for the Future - Theory and Cases (435-466). Croatia: InTech. Zimecs, A., and Ketners, K. (2009). Significance of the Risk Management in Activity of the Small and Medium Enterprises. Scientific Journal of RTU. 3 Series: Economics and Business. 19: 137147.Zimecs, A., and Ketners, K. (2010). Entrepreneurial Decision Substantiation Methodology and Its Impact on Risk Management. Scientific Journal of RTU. 3 Series: Economics and Business. 20: $157-163$. 


\title{
PREKYBOS PASLAUGŲ RIZIKŲ IVERTINIMAS
}

\author{
Inga JANSONE \\ Irina VORONOVA \\ Rygos technikos universitetas, Latvija
}

\begin{abstract}
Santrauka. Tyrimo tikslas - ištirti rizikos rūšis, jų identifikavimo ir klasifikavimo bei ịvertinimo galimybes Latvijos prekybos paslaugų įmonių veikloje. Autoriai sukūrè prekybos paslaugų technologinio proceso rizikų klasifikaciją ir atlikę svarbiausių rizikos veiksnių prekybos paslaugų technologinio proceso etapuose tyrimą sukūrè prekybos paslaugų technologinio proceso rizikos matricą. Rizikos matrica yra kiekybinis rizikos ịvertinimas. Rizikas autoriai suklasifikavo atsižvelgdami ị galimų nuostolių dydị. Ekonominems rizikoms ịvertinti pasitelke ekspertus. Pagal sukurtą įmonių rizikų identifikavimo, klasifikavimo ir ịvertinimo Latvijos prekybos paslaugų sektoriuje modelị autoriai nuo 2004 iki 2011 metų nagrinèjo vidutinius finansinius rodiklius turinčias prekybos paslaugų ịmones Latvijoje. Remiantis šių įmonių ekonomine analize sukurtas rizikos lygio dinamikos ịvertinimo naudojant specialius koeficientus metodas.
\end{abstract}

Reikšminiai žodžiai: rizikos klasifikacija, rizikos ịvertinimas, rizikos matricos, prekybos paslaugų technologinio proceso rizikos. 